\title{
A Sulfuric Acid Nucleation Potential Model for the Atmosphere
}

\author{
Jack Johnson ${ }^{1,2}$ and Coty N. Jen ${ }^{1,2}$
}

1. Chemical Engineering, Carnegie Mellon University, Pittsburgh, PA, 15213, USA

5 2. Center for Atmospheric Particle Studies, Carnegie Mellon University, Pittsburgh, PA, 15213, USA

Correspondence to: Coty N. Jen (cotyj@andrew.cmu.edu)

Abstract. Observations over the last decade have demonstrated that the atmosphere contains potentially hundreds of compounds that can react with sulfuric acid to nucleate stable aerosol particles. Consequently, modeling atmospheric nucleation requires detailed knowledge of nucleation reaction kinetics and spatially and temporally resolved measurements of numerous precursor compounds. This study introduces the Nucleation Potential Model (NPM), a novel nucleation model that dramatically simplifies the diverse reactions between sulfuric acid and any combination of precursor gases. NPM predicts 1$\mathrm{nm}$ nucleation rates are dependent on only two measurable gas concentrations, regardless of whether all precursor gases are known. NPM describes sulfuric acid nucleating with a parameterized base compound at an effective base concentration, [B $\left.\mathrm{B}_{\text {eff }}\right]$. [B $\left.\mathrm{B}_{\text {eff }}\right]$ captures the ability of a compound or mixture to form stable clusters with sulfuric acid and is estimated from measured 1-nm particle concentrations. NPM is applied to experimental and field observations of sulfuric acid nucleation to demonstrate how $\left[\mathrm{B}_{\text {eff }}\right]$ varies for different stabilizing compounds, mixtures, and sampling locations. Analysis of previous field observations shows distinct differences in $\left[\mathrm{B}_{\text {eff }}\right]$ between locations that follow the emission sources and stabilizing compound concentrations for that region. Overall, NPM allows researchers to easily model nucleation across diverse environments and estimate the concentration of non-sulfuric acid precursors using a condensation particle counter.

\section{Introduction}

Atmospheric aerosol particles play an important role in cloud formation and, as a result, Earth's radiation balance. Global climate models estimate that around 50\% of cloud condensation nuclei (CCN) are produced by nucleation (Gordon et al., 2017; Yu and Luo, 2009; Merikanto et al., 2009; Spracklen et al., 2008), whereby gas-phase compounds react and form a stable particle approximately 1-nm in diameter (Jen et al., 2015; Chen et al., 2012). As a result, nucleation influences cloud properties and lifetimes, which subsequently impact Earth's radiation balance (Spracklen et al., 2008, 2006). Therefore, accurate modeling of nucleation rates in the atmosphere is necessary to predict atmospheric aerosol concentrations used in global weather and climate models.

Aerosol nucleation in the troposphere is primarily driven by sulfuric acid (Kuang et al., 2008; Sihto et al., 2006; Sipilä

30 et al., 2010; Lee et al., 2019; Weber et al., 1996, 1997; Kulmala et al., 2004) which reacts with atmospheric bases, like ammonia, to form particles (Kürten et al., 2016; Glasoe et al., 2015; Weber et al., 1998; Kirkby et al., 2011; Jen et al., 2014; 
Coffman and Hegg, 1995; Almeida et al., 2013). Laboratory studies have demonstrated that sulfuric acid nucleates with compounds at rates spanning over seven orders of magnitude (Elm et al., 2016; Jen et al., 2016, 2014; Kürten et al., 2014; Glasoe et al., 2015). The ever-expanding list of compounds includes ammonia (Kirkby et al., 2011; Hanson and Eisele, 2002;

35 Coffman and Hegg, 1995), amines (Glasoe et al., 2015; Kurtén et al., 2008; Jen et al., 2014), diamines (Elm et al., 2016; Jen et al., 2016; Elm et al., 2017), alcohol amines (Xie et al., 2017), organic acids (Zhao et al., 2009; Zhang et al., 2004), oxidized organics (Riccobono et al., 2012, 2014; Ehn et al., 2014; Zhao et al., 2013), water (Kulmala et al., 1998; Merikanto et al., 2007), and ions (Eisele et al., 2006; Kirkby et al., 2011). Additionally, sulfuric acid has been shown to nucleate with multiple compounds synergistically, such as dimethylamine/ammonia (Glasoe et al., 2015; Yu et al., 2012) and oxidized organics/ammonia (Lehtipalo et al., 2018).

Currently, three classes of nucleation models are used to estimate atmospheric nucleation rates, but no existing model is capable of capturing the true complexity of atmospheric nucleation reactions. First, power-law nucleation models estimate nucleation rates from empirically derived power-law functions fitted from measured nucleation rates of sulfuric acid with various precursor gas concentrations (Yao et al., 2018; Glasoe et al., 2015; Kirkby et al., 2011). These power-law models have been used to predict nucleation rates in areas such as Asian megacities, the Amazon Rainforest, and globally (Yao et al., 2018; Zhao et al., 2020; Dunne et al., 2016). However, the power-law models are typically only dependent on two to three nucleation precursor concentrations, and thus cannot accurately predict nucleation rates in areas where numerous and unknown compounds are nucleating with sulfuric acid. Computational chemistry nucleation models compute formation free energies of clusters containing sulfuric acid and stabilizing compounds in order to numerically solve the cluster balance equations (Ortega et al., 2012; Myllys et al., 2018; McGrath et al., 2012; Olenius et al., 2013; Elm, 2019; Yu et al., 2018). While computational chemistry models can rigorously show the formation pathways of sulfuric acid clusters, the method becomes too computationally expensive when determining formation pathways for a mixture of nucleating compounds. Finally, acid-base nucleation models are based on experimentally observed nucleation kinetics that have demonstrated particles form via the sequential addition of acid and base molecules (Chen et al., 2012; Jen et al., 2014; Kürten et al., 2018). These experiments use a chemical ionization mass spectrometer (CIMS) to measure gas and cluster concentrations to estimate cluster evaporation rates. While acid-base models can experimentally determine the reaction kinetics of sulfuric acid clusters, finding evaporation rates for numerous cluster types is experimentally arduous due to its dependence on nucleation precursor composition and concentration. While each model type provides unique and beneficial information about how sulfuric acid nucleates, they fail to predict particle nucleation rates in complex mixtures, such as the atmosphere, and require high spatial and temporal speciated precursor measurements to accurately predict global nucleation rates.

Currently, most global climate models do not account for sulfuric acid nucleation, with a few models including powerlaw nucleation models (Gordon et al., 2017; Zhao et al., 2020). However, experimental observations indicate that even low concentrations of other stabilizing compounds can enhance sulfuric acid nucleation rates beyond that predicted from models (Li et al., 2020; Wang et al., 2018). Moreover, emission inventories used in global climate models only contain sulfur dioxide concentrations and ammonia concentrations. Furthermore, only sparse measurements, both in time and space, exist of the 
numerous precursor compounds in the atmosphere. Combined, these factors contribute to significant model error in predicting aerosol number concentrations in regions with no dominant nucleation pathway.

This study presents a generalized, semi-empirical model for sulfuric acid nucleation, known as the Nucleation Potential Model (NPM), that simplifies the numerous and often unknown nucleation reactions into a single reaction pathway.

70 NPM reflects how sulfuric acid reacts with an effective base compound and predicts 1-nm nucleation rates from sulfuric acid and a parameterized base concentration $\left(\left[\mathrm{B}_{\mathrm{eff}}\right]\right)$. $\left[\mathrm{B}_{\mathrm{eff}}\right]$ captures the combined concentrations of compounds and their ability to stabilize sulfuric acid clusters. This parameterized concentration is estimated from measured 1-nm particle concentrations formed from controlled reactions between sulfuric acid and a complex mixture. Consequently, use of NPM circumvents the need to deploy a mass spectrometer to measure numerous precursor concentrations and instead relies on a more portable and

75 cost-effective condensation particle counter (CPC). This study demonstrates the dependencies of [ $\mathrm{B}_{\text {eff }}$ from a variety of stabilizing gas mixtures and its potential to predict 1-nm nucleation rates across diverse regions of the world.

\section{Methodology}

\subsection{Model Description}

The Nucleation Potential Model (NPM) generalizes the formation of 1-nm particles from sulfuric acid nucleation as

80 a series of second-order reactions. Reaction 1 shows the reaction pathway for the NPM, where $n$ represents the number of sulfuric acid $(A)$ and base $(B)$ molecules in a cluster. $N_{n}$ denotes the cluster size with $N_{l}$ as the monomer (i.e., one sulfuric acid molecule with any number of base or other attached compounds) up to $N_{4}$ as the tetramer. The reaction pathway is based on the most probable pathway for sulfuric acid and base clusters to form, with less probable pathways excluded to reduce model calculation time and complexity (Olenius et al., 2017). The final step in Reaction 1 is the formation of the tetramer, $N_{4}$. At the

85 tetramer size, the particles are approximately $1 \mathrm{~nm}$ in diameter or $1.3 \mathrm{~nm}$ in mobility diameter (Chen et al., 2012; Jen et al., 2015; Larriba et al., 2011). Cluster balance equations (i.e., rates laws) for Reaction 1 are provided in the supplementary information (SI, Equation S1).

$$
\begin{gathered}
A_{1}+B_{\text {eff }} \stackrel{k}{\rightarrow} A_{1} \cdot B_{\text {eff }} \\
N_{n}=A_{n} \cdot B_{n} \\
N_{1}+N_{1} \stackrel{k}{\rightarrow} N_{2} \\
N_{1}+N_{2} \stackrel{k}{\rightarrow} N_{3} \\
N_{2}+N_{2} \stackrel{k}{\rightarrow} N_{4} \\
N_{1}+N_{3} \stackrel{k}{\rightarrow} N_{4}
\end{gathered}
$$

\section{Reaction 1}


The forward reaction constant is assumed to be equal for all clusters at $k=4.2 \times 10^{-10} \mathrm{~cm}^{3} \mathrm{~s}^{-1}$ and is the collision rate constant calculated using parameters estimated from density functional theory and bulk properties (Ortega et al., 2012). The effective base concentration $\left(\left[\mathrm{B}_{\text {eff }}\right]\right)$ represents the stabilization effects that a compound or mixture of compounds has on the formation rate of sulfuric acid clusters. $\left[\mathrm{B}_{\mathrm{eff}}\right]$ also depends on the nucleation precursors' concentrations, composition, temperature, and humidity. A compound that effectively stabilizes sulfuric acid clusters has a higher value for [ $\left.\mathrm{B}_{\text {eff }}\right]$ than a weaker stabilizing compound. [ $\left.\mathrm{B}_{\mathrm{eff}}\right]$ is numerically solved from the cluster balance equations (Equation $\mathrm{S} 1$ ) with inputs of the initial concentration of sulfuric acid monomer $\left(\left[\mathrm{A}_{1}\right]_{0}\right)$, the final concentration of nucleated 1-nm particles (i.e., $\left.\left[\mathrm{N}_{4}\right]\right)$, and nucleation reaction time $\left(\mathrm{t}_{\text {nucl. }}\right)$.

[ $\left.\mathrm{B}_{\text {eff }}\right]$ was determined for nucleating systems consisting of sulfuric acid and various combinations of atmospherically relevant bases reacting in an extremely clean and repeatable flow reactor at $300 \mathrm{~K}$ and $20 \% \mathrm{RH}$ (Fomete et al., 2021). [ $\left.\mathrm{A}_{1}\right]_{\mathrm{o}}$ and base concentrations ([B]) were measured with a custom-built, transverse atmospheric pressure acetate/hydronium chemical ionization inlet coupled to a long time-of-flight mass spectrometer (Pittsburgh Cluster CIMS, PCC) (Fomete et al., 2021). The bases included dilute concentrations of ammonia $\left(\mathrm{NH}_{3}\right)$, methylamine $\left(\mathrm{MA}, \mathrm{CH}_{3} \mathrm{NH}_{2}\right)$, dimethylamine $\left(\mathrm{DMA},\left(\mathrm{CH}_{3}\right)_{2} \mathrm{NH}\right)$, and trimethylamine (TMA, $\mathrm{C}_{3} \mathrm{H}_{9} \mathrm{~N}$ ) (Fomete et al., 2021; Zollner et al., 2012). The $\mathrm{t}_{\text {nucl }}$ was determined to be $2 \mathrm{~s}$ from the modeled centerline velocity of the reactor (Hanson et al., 2017; Panta et al., 2012). The concentrations of $\mathrm{N}_{4}$ and larger particles were measured with a 1-nm versatile water-based Condensation Particle Counter (vwCPC, TSI 3789) (Hering et al., 2017). The flow tube was optimized to minimize the concentration of particles $>1-\mathrm{nm}$ by lowering the sulfuric acid monomer concentration $\left(\left[\mathrm{A}_{1}\right]_{\mathrm{o}}\right)$. This was done to keep below the maximum particle concentration of the vwCPC and minimize particle coagulation. See Figure S1 for more details on 1-nm particle optimization experiments.

\section{Results and Discussion}

\subsection{Experimental Model Validation}

Figure 1 shows [ $\left.\mathrm{B}_{\mathrm{eff}}\right]$ for the single component injections of $\mathrm{NH}_{3}, \mathrm{MA}$, DMA, and TMA in the sulfuric acid reactor.

$110\left[\mathrm{~A}_{1}\right]_{\mathrm{o}}$ is approximately $1.4 \times 10^{8} \mathrm{~cm}^{-3}$, and $\mathrm{t}_{\text {nucl }}$ is approximately $2 \mathrm{~s}$. These atmospherically relevant compounds have previously been shown to nucleate with sulfuric acid at different rates (Jen et al., 2016, 2014; Kurtén et al., 2008; Glasoe et al., 2015). Each compound was injected at various measured [B], ranging from $\sim 1$ to $\sim 30 \mathrm{pptv}$. From Fig. 1, [Beff] for $\mathrm{NH}_{3}$ remains unchanged at approximately $10-15$ pptv across the entire $\left[\mathrm{NH}_{3}\right]$ range. This constant $\left[\mathrm{B}_{\text {eff }}\right]$ trend suggests that $\mathrm{NH}_{3}$ does not significantly stabilize sulfuric acid clusters and enhance nucleation rates under the experimental conditions in the flow tube.

115 This is expected due to the relatively short nucleation time when compared to previous experimental studies. In contrast, [Beff] increases up to $\sim 40$ pptv with increasing [MA], demonstrating that this compound enhances sulfuric acid nucleation greater than $\mathrm{NH}_{3}$. The $\left[\mathrm{B}_{\text {eff }}\right]$ curves for DMA and TMA exhibit higher slopes than MA and $\mathrm{NH}_{3}$, indicating that DMA and TMA substantially enhance sulfuric acid nucleation rates at low $[\mathrm{B}]$. Furthermore, at $[\mathrm{B}]=10 \mathrm{pptv}$, [Beff for DMA and TMA are two to three times higher than MA and four to six times higher than $\mathrm{NH}_{3}$. This indicates that DMA and TMA have a much 
120 stronger interaction with sulfuric acid clusters than $\mathrm{MA}$ and $\mathrm{NH}_{3}$. Note, the plateau in $\left[\mathrm{B}_{\text {eff }}\right]$ occurs when a significant concentration of $>1-\mathrm{nm}$ particles at high $[\mathrm{B}]$ increases the coagulation rate beyond what is predicted by the NPM. The relative potency of these compounds in enhancing nucleation is consistent with previously published results indicating that the NPM is correctly capturing the nucleation potency of $\mathrm{NH}_{3}$, MA, DMA, and TMA (Glasoe et al., 2015; Jen et al., 2014; Kürten et al., 2018).

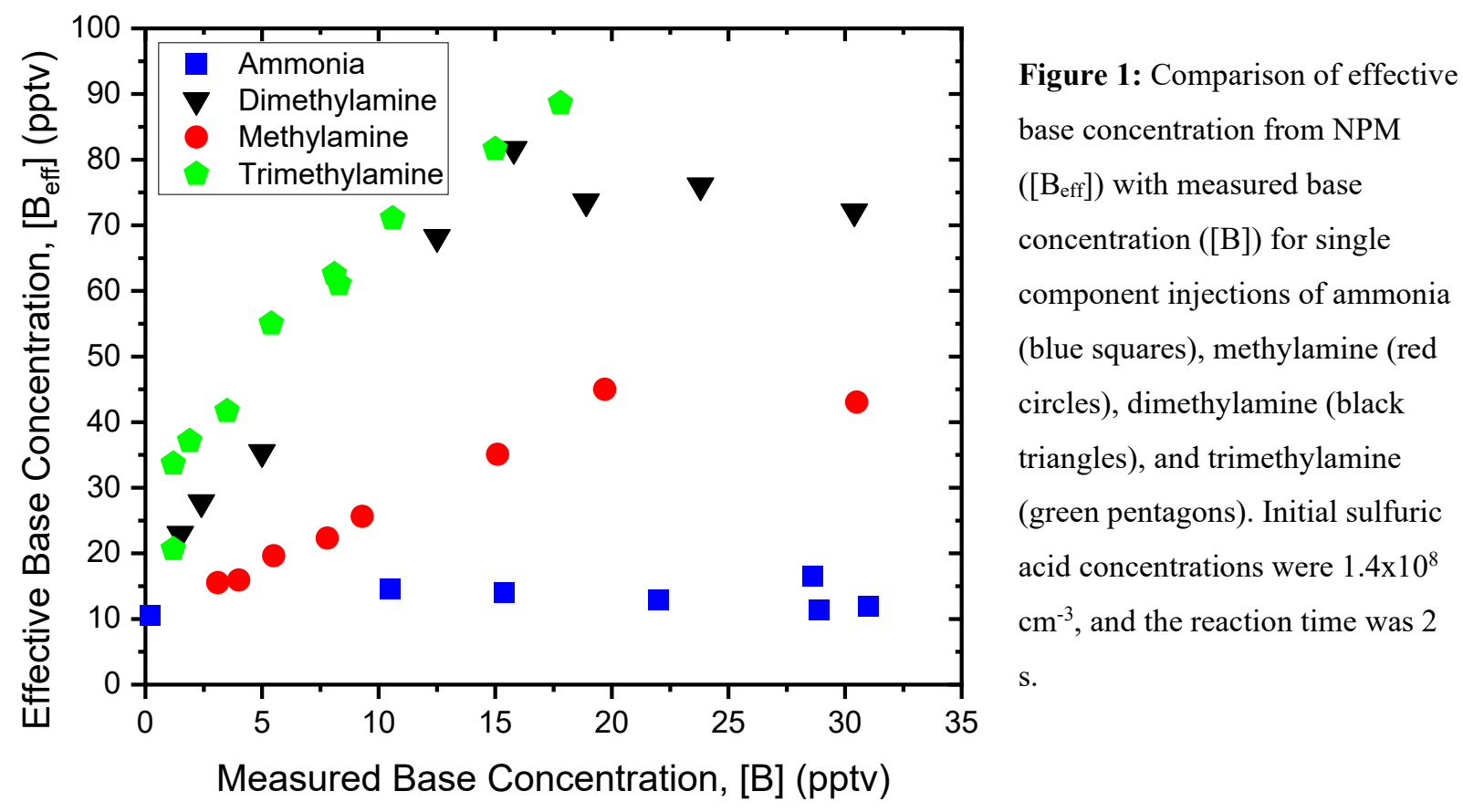

NPM was also used to determine [ $\left.\mathrm{B}_{\text {eff }}\right]$ for more complex mixtures of nucleation precursors. Figure 2 shows [ $\left.\mathrm{B}_{\text {eff }}\right]$ from simultaneous injections of $\mathrm{NH}_{3}$ at 73 pptv and varying [DMA] into the sulfuric acid flow reactor. $\mathrm{NH}_{3}$ and DMA mixture injections have higher values for $\left[\mathrm{B}_{\text {eff }}\right]$, up to $120 \mathrm{pptv}$, which are especially prominent at higher concentrations of DMA. At $[\mathrm{B}]=20 \mathrm{pptv},\left[\mathrm{B}_{\text {eff }}\right]$ for the mixture of $\mathrm{NH}_{3}$ and DMA is significantly higher than linear addition of the [ $\mathrm{B}_{\text {eff }}$ from individual DMA and $\mathrm{NH}_{3}, \sim 110 \mathrm{pptv}$ compared to $\sim 80$ pptv, respectively. This suggests that DMA and $\mathrm{NH}_{3}$ react synergistically with sulfuric acid to form particles. The synergist effect is due to ammonia's ability to stabilize sulfuric acid clusters long enough for DMA to collide and react with the sulfuric acid-ammonia clusters (Myllys et al., 2019; DePalma et al., 2012; Glasoe et al., 2015). 
Figure 2: Comparison of

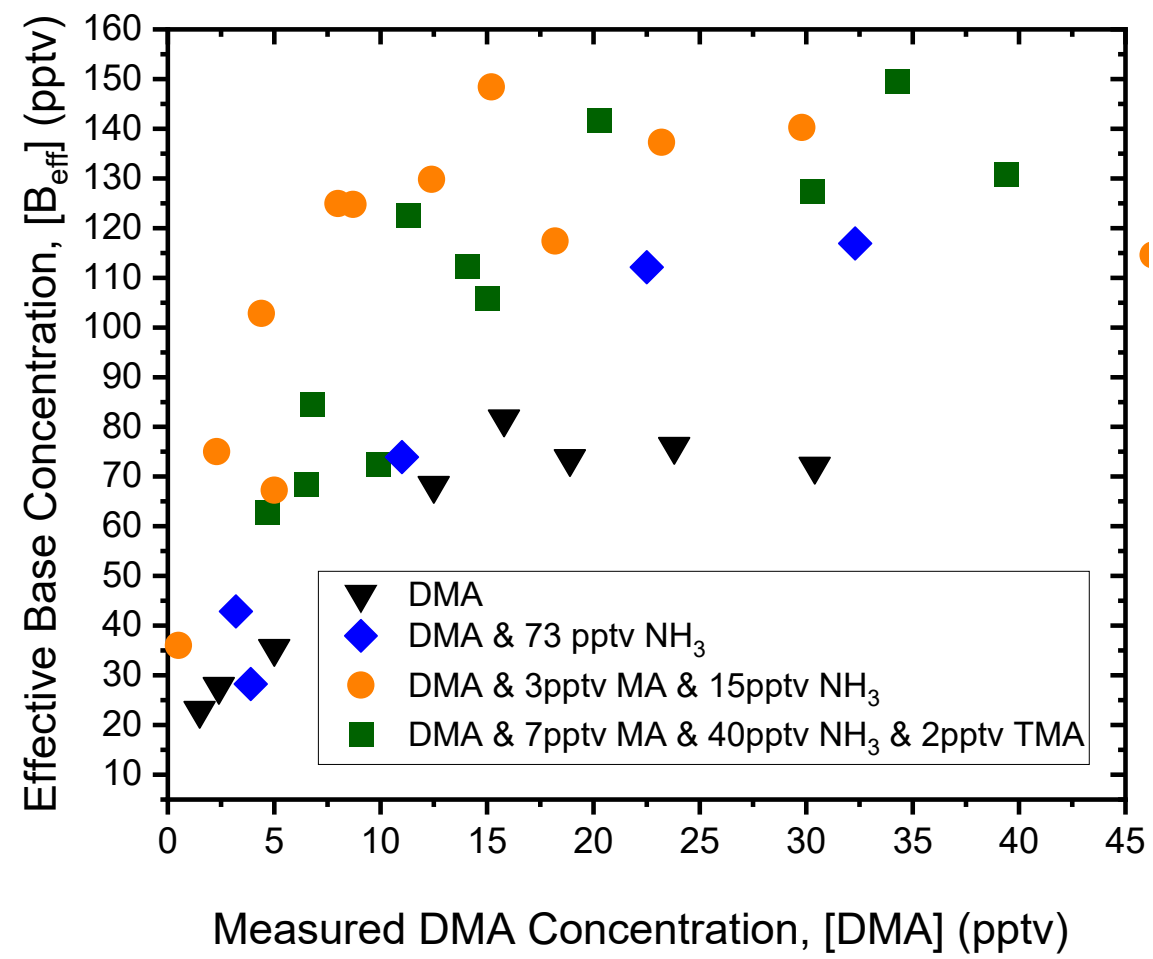

$\left[\mathrm{B}_{\mathrm{eff}}\right]$ and measured dimethylamine (DMA) concentration for dualcomponent injections. Mixture experiments for DMA (black triangles), DMA with 73 pptv $\mathrm{NH}_{3}$ (blue diamonds), DMA with 7 pptv MA, 40 pptv $\mathrm{NH}_{3}$ and 2 pptv TMA (green squares), and DMA with 3 pptv MA and 15 pptv $\mathrm{NH}_{3}$ (orange circles). The sulfuric acid concentration was $1.4 \times 10^{8}$ $\mathrm{cm}^{-3}$ and a nucleation time of $\sim 2 \mathrm{~s}$.

Figure 2 also shows mixtures containing combinations of $\mathrm{NH}_{3}, \mathrm{MA}$, and TMA with varying amounts of DMA. Again, an increase in [DMA] leads to an increase in [ $\mathrm{B}_{\text {eff }}$, and all mixture curves display an enhancement to nucleation compared to pure sulfuric acid-DMA nucleation. A slight variation in [ $\mathrm{B}_{\text {eff }}$ between the 3 and 4 component mixture curves can be observed since MA, $\mathrm{NH}_{3}$, and TMA concentrations do not change significantly. Additionally, [Beff] is $\sim 60$ pptv at 10 pptv of DMA injected in the DMA and $\mathrm{NH}_{3}$ curve in Fig. 2, while [ $\left.\mathrm{B}_{\text {eff }}\right]$ is $\sim 100$ pptv at 10 pptv of DMA injected into the 3 and 4 component mixture curves in Fig. 2. These observations imply that $\mathrm{NH}_{3}$ and DMA synergistic reactions are still the dominant nucleation pathway and contribute the most to [ $\left.\mathrm{B}_{\text {eff }}\right]$ while MA and TMA potentially react separately with sulfuric acid to form particles. Overall, observations from Fig. 2 indicate that NPM can determine how a complex mixture of compounds enhances sulfuric 145 acid nucleation solely using measurements from the vwCPC.

A significant amount of scatter in $\left[\mathrm{B}_{\mathrm{eff}}\right]$ is observed for the mixture experiments in Fig. 2 compared to the singlecomponent results (Figure 1). This scatter is potentially due to inconsistent mixing of alkylamines within the injection stream into the flow reactor and/or mixing inside the flow reactor. The overall uncertainty in $\left[\mathrm{B}_{\text {eff }}\right]$ is also primarily influenced by the uncertainty in the particle size distribution, and to a lesser extent the particle concentration measurements, measured concentrations of gas-phase compounds, the flow dynamics within the flow reactor, temperature, and humidity. The estimated systematic uncertainty in PCC measurement of $\left[\mathrm{A}_{1}\right]_{\mathrm{o}}$ and $[\mathrm{B}]$ are approximately a factor a two and would not impact the trends 
observed in Figures 1 and 2 (Zhao et al., 2010; Simon et al., 2016; Erupe et al., 2010). Currently, daily baseline measurements were taken following the procedure in Fomete et al. (2021) to ensure consistent and stable concentrations of both gas-phase and particle-phase compounds within the flow reactor. Furthermore, the measured particle concentrations are not corrected for detection efficiency as it is not known for electrically neutral sulfuric acid-amine 1-nm particles. The detection efficiency of clusters composed of sulfuric acid and amines/ammonia is normally assumed to be similar, and thus accounting for this will not impact the reported $\left[\mathrm{B}_{\text {eff }}\right]$. In future studies, electrically neutral size distributions will be measured to constrain the coagulation rates in NPM.

\subsection{Application of Nucleation Potential Model to the Atmosphere}

The NPM was also used to determine how the concentration of stabilizing compounds vary around the world. Nucleation rates of 1-nm particles ( $\mathrm{J}_{1 \mathrm{~nm}}$, which equals the formation rate of $\mathrm{N}_{4}$ ) and sulfuric acid concentrations were obtained from previous field campaigns including in Hyytiälä Forest, Finland (Sihto et al., 2006); Mexico City, Mexico (Iida et al., 2008); Atlanta, Georgia (McMurry and Eisele, 2005); Boulder, Colorado (Eisele et al., 2006); and Beijing, China (Cai et al., 2021). The equations of the NPM (Equation S1) were solved at steady state to determine [ $\left.B_{\text {eff }}\right]$ from the observed $J_{1 \mathrm{~nm}}$, and coagulation rates to pre-existing particles were calculated from the Fuch's surface area for Atlanta, Boulder, Mexico City, and Hyytiallä (Kuang et al., 2010). Figure 3 shows how [ $B_{\text {eff }}$ varies based on measured $\left[A_{1}\right]$. Each location exhibits clear differences in the range of $\left[\mathrm{B}_{\text {eff }}\right]$ regardless of measured sulfuric acid concentration. For example, Beijing shows the highest $\left[\mathrm{B}_{\text {eff }}\right]$ at $\sim 15$ pptv of any location, indicating high concentrations of potent stabilizing compounds (e.g., DMA). The [Beff] for Beijing are consistent with the measured [ $\left.\mathrm{B}_{\text {eff }}\right]$ of single-component injection of [DMA] 2 pptv (Figure 1) which matches the measured $[D M A]=2-3$ pptv concentration at Beijing (Cai et al., 2021). Interestingly, the [B $B_{\text {eff }}$ of Beijing does not reflect the higher [Beff from synergistic sulfuric acid nucleation with ammonia and DMA (Fig. 2), suggesting that other compounds could be preventing this synergistic nucleation pathway from dominating in Beijing during the time period that nucleation rates were measured. In addition, the $\left[\mathrm{B}_{\text {eff }}\right]$ observed in Beijing contrasts with the other locations. Specifically, Hyytiälä Forest, where $\left[\mathrm{B}_{\text {eff }}\right] 2$ pptv, is lower than even sulfuric acid-ammonia nucleation (Fig. 1) and agrees with the previously measured [DMA]

$175<1$ pptv in this area. (Sipilä et al., 2015). Mexico City and Atlanta are moderately polluted cities and exhibited [Beff $\sim 4-8$ pptv and better matches sulfuric acid-ammonia nucleation (Fig. 1). Differences in temperature and relative humidity also play a role in $\left[\mathrm{B}_{\text {eff }}\right]$. However, these differences may not be significant as $\left[\mathrm{B}_{\text {eff }}\right]$ between the Hyytiälä Forest $\left(\sim{ }^{\circ} \mathrm{C}\right)$ and Boulder, $\mathrm{CO}$ $\left(\sim 22^{\circ} \mathrm{C}\right)$ are similar. Future work will include the direct measurement of [ $\left.\mathrm{B}_{\mathrm{eff}}\right]$ via controlled reactions of atmospheric air with a known concentration of sulfuric acid for a more direct comparison of laboratory and field-measurement results. Regardless, these observations demonstrate that $\left[\mathrm{B}_{\text {eff }}\right]$ reflects the composition and concentration of stabilizing compounds detected in the atmosphere and can be used to model sulfuric acid nucleation rates in diverse areas. 


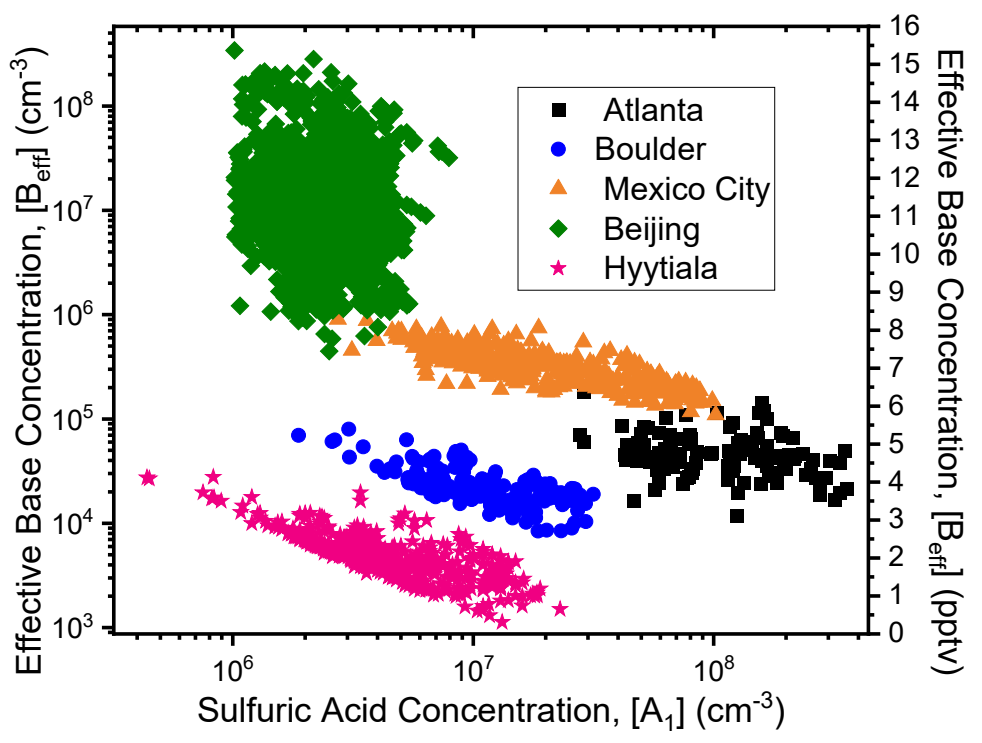

Figure 3: Comparison of the effective base concentration $\left(\left[\mathrm{B}_{\mathrm{eff}}\right]\right)$ at various sulfuric acid concentrations $\left(\left[\mathrm{A}_{1}\right]\right)$ across five locations: green diamonds Beijing, China; red triangles Mexico City, Mexico; black squares Atlanta, Georgia; blue circles Boulder, Colorado; and pink stars Hyytiälä Forest, Finland.

Figure 4 compares $\left[\mathrm{B}_{\text {eff }}\right]$ to the weighted amine concentration ([DMA] $\left.+0.2[\mathrm{TMA}]\right)$ measured in Beijing (Cai et al., 2021). In Figure 4, $\left[\mathrm{B}_{\mathrm{eff}}\right]$ and the weighted amine concentration are positively correlated with a slope of 0.91 , indicating that

$185\left[\mathrm{~B}_{\text {eff }}\right]$ is sensitive to the amine concentration over a wide range of sulfuric acid concentrations. Furthermore, the data were divided into October, November, and December (2018) to explore how the seasons may affect precursor concentrations and nucleation rates. For October, more variation in $\left[\mathrm{B}_{\mathrm{eff}}\right]$ is observed when compared to the weighted amine concentration. This variation could be due to weather and temperature changes that enhance or reduce sulfuric acid nucleation rates. Additionally, other compounds likely exist in Beijing that nucleate with sulfuric acid which were not reported. November and December are significantly colder in Beijing, which would correlate with higher fuel (e.g., coal) burning and greater emissions of sulfuric acid and amines. 


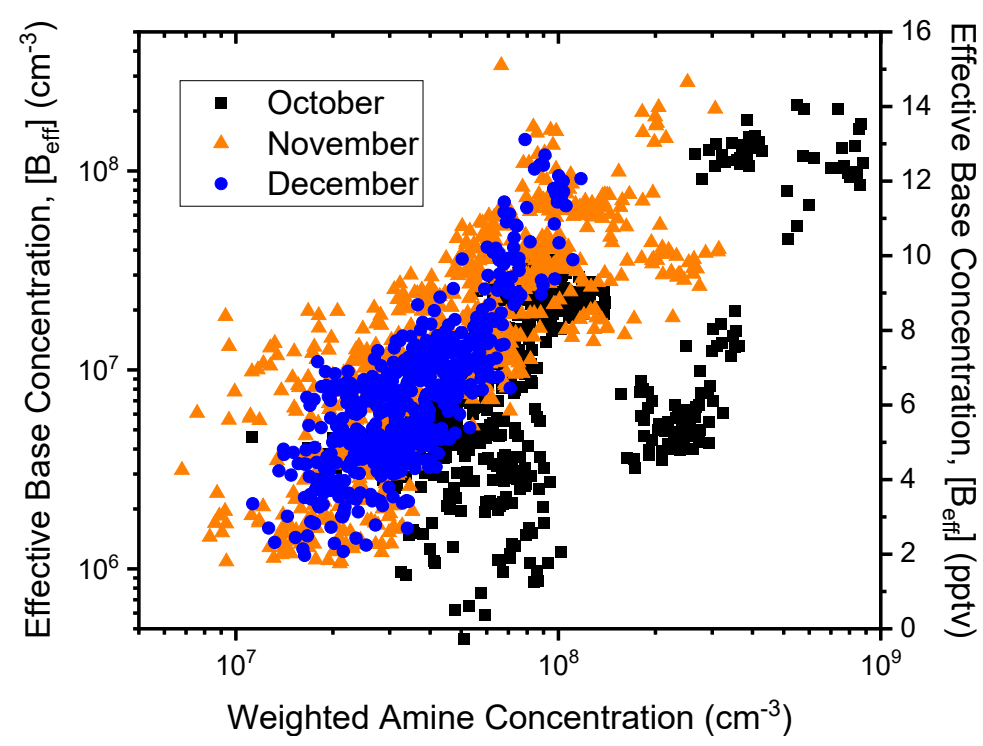

Figure 4: Comparison of effective base concentration from NPM ([B $\left.\mathrm{B}_{\text {eff }}\right]$ ) with the weighted amine concentration measured in Beijing, China in 2018. October measurements are black squares, November orange triangles, and December blue circles.

\section{Conclusion}

The Nucleation Potential Model (NPM) is presented that simplifies predicting sulfuric acid nucleation rates in the complex atmosphere with two precursor concentrations: sulfuric acid and an effective base concentration ([ $\left.\mathrm{B}_{\text {eff }}\right]$ ). The effective base concentration captures the amounts and types of stabilizing compounds that enhance sulfuric acid nucleation. NPM was applied to systems containing up to four atmospherically relevant bases reacting with sulfuric acid in a flow reactor. [Beff] was determined from measured 1-nm particle concentrations, and its value depends heavily on the presence of strong stabilizing compounds, such as DMA and TMA, and their concentrations. [ $\left.\mathrm{B}_{\text {eff }}\right]$ values also reflect synergistic effects between multiple compounds like DMA and ammonia. Finally, NPM was also used to calculate [ $\left.\mathrm{B}_{\text {eff }}\right]$ in various locations worldwide. Results show how the potency of the complex mixtures varies between polluted and unpolluted environments, and these observations did not require every potential stabilizing compound nucleating with sulfuric acid to be measured. $\left[\mathrm{B}_{\mathrm{eff}}\right]$ can be determined from measured 1-nm particle concentrations produced from controlled reactions between a specified sulfuric acid concentration and a complex mixture. NPM complements current speciated measurements, such as those from a CIMS, by providing additional insights into the potency of combined atmospheric compounds at enhancing sulfuric acid nucleation. NPM and further measurement of [ $\left.B_{\text {eff }}\right]$ in diverse locations and seasons will help improve aerosol number concentrations predictions, reduce error in global climate models, and expand understanding of the anthropogenic contribution to Earth's radiative balance.

Data Availability: Data is available upon request and will be uploaded to The Index of Chamber Atmospheric Research in the United States (ICARUS). 
Author Contribution: JJ and CNJ both conceived of the model and experimental setup. JJ performed the experiments and data analysis. JJ and CNJ contributed to writing the paper.

Competing Interests: The authors declare that they have no conflict of interest

Acknowledgments: The authors thank Drs. Runlong Cai and Jingkun Jiang for providing their measurements from Beijing,

China. In addition, the authors acknowledge the support from NSF AGS-1913504 and Aerosol Dynamics Inc. for lending the TSI 3789 vwCPC.

Financial Support: National Science Foundation AGS-1913504.

\section{References}

Almeida, J., Schobesberger, S., Kürten, A., Ortega, I. K., Kupiainen-Määttä, O., Praplan, A. P., Adamov, A., Amorim, A., Bianchi, F., Breitenlechner, M., David, A., Dommen, J., Donahue, N. M., Downard, A., Dunne, E., Duplissy, J., Ehrhart, S., Flagan, R. C., Franchin, A., Guida, R., Hakala, J., Hansel, A., Heinritzi, M., Henschel, H., Jokinen, T., Junninen, H., Kajos, M., Kangasluoma, J., Keskinen, H., Kupc, A., Kurtén, T., Kvashin, A. N., Laaksonen, A., Lehtipalo, K., Leiminger, M., Leppä, J., Loukonen, V., Makhmutov, V., Mathot, S., McGrath, M. J., Nieminen, T., Olenius, T., Onnela, A., Petäjä, T., Riccobono, F., Riipinen, I., Rissanen, M., Rondo, L., Ruuskanen, T., Santos, F. D., Sarnela, N., Schallhart, S., Schnitzhofer, R., Seinfeld,

225 J. H., Simon, M., Sipilä, M., Stozhkov, Y., Stratmann, F., Tomé, A., Tröstl, J., Tsagkogeorgas, G., Vaattovaara, P., Viisanen, Y., Virtanen, A., Vrtala, A., Wagner, P. E., Weingartner, E., Wex, H., Williamson, C., Wimmer, D., Ye, P., Yli-Juuti, T., Carslaw, K. S., Kulmala, M., Curtius, J., Baltensperger, U., Worsnop, D. R., Vehkamäki, H., and Kirkby, J.: Molecular understanding of sulphuric acid-amine particle nucleation in the atmosphere, Nature, 502, 359-363, https://doi.org/10.1038/nature12663, 2013.

230 Cai, R., Yan, C., Yang, D., Yin, R., Lu, Y., Deng, C., Fu, Y., Ruan, J., Li, X., Kontkanen, J., Zhang, Q., Kangasluoma, J., Ma, Y., Hao, J., Worsnop, D. R., Bianchi, F., Paasonen, P., Kerminen, V.-M., Liu, Y., Wang, L., Zheng, J., Kulmala, M., and Jiang, J.: Sulfuric acid-amine nucleation in urban Beijing, Atmospheric Chem. Phys., 21, 2457-2468, https://doi.org/10.5194/acp21-2457-2021, 2021.

Chen, M., Titcombe, M., Jiang, J., Jen, C., Kuang, C., Fischer, M. L., Eisele, F. L., Siepmann, J. I., Hanson, D. R., Zhao, J., and McMurry, P. H.: Acid-base chemical reaction model for nucleation rates in the polluted atmospheric boundary layer, Proc. Natl. Acad. Sci. U. S. A., 109, 18713-18718, https://doi.org/10.1073/pnas.1210285109, 2012.

Coffman, D. J. and Hegg, D. A.: A preliminary study of the effect of ammonia on particle nucleation in the marine boundary layer, J. Geophys. Res. Atmospheres, 100, 7147-7160, https://doi.org/10.1029/94JD03253, 1995.

DePalma, J. W., Bzdek, B. R., Doren, D. J., and Johnston, M. V.: Structure and Energetics of Nanometer Size Clusters of 240 Sulfuric Acid with Ammonia and Dimethylamine, J. Phys. Chem. A, 116, 1030-1040, https://doi.org/10.1021/jp210127w, 2012.

Dunne, E. M., Gordon, H., Kürten, A., Almeida, J., Duplissy, J., Williamson, C., Ortega, I. K., Pringle, K. J., Adamov, A., Baltensperger, U., Barmet, P., Benduhn, F., Bianchi, F., Breitenlechner, M., Clarke, A., Curtius, J., Dommen, J., Donahue, N. M., Ehrhart, S., Flagan, R. C., Franchin, A., Guida, R., Hakala, J., Hansel, A., Heinritzi, M., Jokinen, T., Kangasluoma, J., Kirkby, J., Kulmala, M., Kupc, A., Lawler, M. J., Lehtipalo, K., Makhmutov, V., Mann, G., Mathot, S., Merikanto, J., Miettinen, P., Nenes, A., Onnela, A., Rap, A., Reddington, C. L. S., Riccobono, F., Richards, N. A. D., Rissanen, M. P., Rondo, L., Sarnela, N., Schobesberger, S., Sengupta, K., Simon, M., Sipilä, M., Smith, J. N., Stozkhov, Y., Tomé, A., Tröstl, J., Wagner, P. E., Wimmer, D., Winkler, P. M., Worsnop, D. R., and Carslaw, K. S.: Global atmospheric particle formation from CERN CLOUD measurements, Science, 354, 1119-1124, https://doi.org/10.1126/science.aaf2649, 2016. 
Ehn, M., Thornton, J. A., Kleist, E., Sipilä, M., Junninen, H., Pullinen, I., Springer, M., Rubach, F., Tillmann, R., Lee, B., Lopez-Hilfiker, F., Andres, S., Acir, I.-H., Rissanen, M., Jokinen, T., Schobesberger, S., Kangasluoma, J., Kontkanen, J., Nieminen, T., Kurtén, T., Nielsen, L. B., Jørgensen, S., Kjaergaard, H. G., Canagaratna, M., Maso, M. D., Berndt, T., Petäjä, T., Wahner, A., Kerminen, V.-M., Kulmala, M., Worsnop, D. R., Wildt, J., and Mentel, T. F.: A large source of low-volatility secondary organic aerosol, Nature, 506, 476, https://doi.org/10.1038/nature13032, 2014.

255 Eisele, F. L., Lovejoy, E. R., Kosciuch, E., Moore, K. F., Mauldin, R. L., Smith, J. N., McMurry, P. H., and Iida, K.: Negative atmospheric ions and their potential role in ion-induced nucleation, J. Geophys. Res. Atmospheres, 111, https://doi.org/10.1029/2005JD006568, 2006.

Elm, J.: An Atmospheric Cluster Database Consisting of Sulfuric Acid, Bases, Organics, and Water, ACS Omega, 4, 1096510974, https://doi.org/10.1021/acsomega.9b00860, 2019.

260 Elm, J., Jen, C. N., Kurtén, T., and Vehkamäki, H.: Strong Hydrogen Bonded Molecular Interactions between Atmospheric Diamines and Sulfuric Acid, J. Phys. Chem. A, 120, 3693-3700, https://doi.org/10.1021/acs.jpca.6b03192, 2016.

Elm, J., Passananti, M., Kurtén, T., and Vehkamäki, H.: Diamines Can Initiate New Particle Formation in the Atmosphere, J. Phys. Chem. A, 121, 6155-6164, https://doi.org/10.1021/acs.jpca.7b05658, 2017.

Erupe, M. E., Benson, D. R., Li, J., Young, L.-H., Verheggen, B., Al-Refai, M., Tahboub, O., Cunningham, V., Frimpong, F., 265 Viggiano, A. A., and Lee, S.-H.: Correlation of aerosol nucleation rate with sulfuric acid and ammonia in Kent, Ohio: An atmospheric observation, J. Geophys. Res. Atmospheres, 115, https://doi.org/10.1029/2010JD013942, 2010.

Fomete, S. K. W., Johnson, J. S., Casalnuovo, D., and Jen, C. N.: A tutorial guide on new particle formation experiments using a laminar flow reactor, J. Aerosol Sci., 157, 105808, https://doi.org/10.1016/j.jaerosci.2021.105808, 2021.

Glasoe, W. A., Volz, K., Panta, B., Freshour, N., Bachman, R., Hanson, D. R., McMurry, P. H., and Jen, C.: Sulfuric acid nucleation: An experimental study of the effect of seven bases, J. Geophys. Res. Atmospheres, 120, 1933-1950, https://doi.org/10.1002/2014JD022730, 2015.

Gordon, H., Kirkby, J., Baltensperger, U., Bianchi, F., Breitenlechner, M., Curtius, J., Dias, A., Dommen, J., Donahue, N. M., Dunne, E. M., Duplissy, J., Ehrhart, S., Flagan, R. C., Frege, C., Fuchs, C., Hansel, A., Hoyle, C. R., Kulmala, M., Kürten, A., Lehtipalo, K., Makhmutov, V., Molteni, U., Rissanen, M. P., Stozkhov, Y., Tröstl, J., Tsagkogeorgas, G., Wagner, R.,

275 Williamson, C., Wimmer, D., Winkler, P. M., Yan, C., and Carslaw, K. S.: Causes and importance of new particle formation in the present-day and preindustrial atmospheres, J. Geophys. Res. Atmospheres, 122, 8739-8760, https://doi.org/10.1002/2017JD026844, 2017.

Hanson, D. R. and Eisele, F. L.: Measurement of prenucleation molecular clusters in the $\mathrm{NH}_{3}, \mathrm{H}_{2} \mathrm{SO}_{4}, \mathrm{H}_{2} \mathrm{O}$ system, J Geophys Res, 107, 4158, https://doi.org/10.1029/2001jd001100, 2002.

280 Hanson, D. R., Bier, I., Panta, B., Jen, C. N., and McMurry, P. H.: Computational Fluid Dynamics Studies of a Flow Reactor: Free Energies of Clusters of Sulfuric Acid with NH3 or Dimethyl Amine, J. Phys. Chem. A, 121, 3976-3990, https://doi.org/10.1021/acs.jpca.7b00252, 2017.

Hering, S. V., Lewis, G. S., Spielman, S. R., Eiguren-Fernandez, A., Kreisberg, N. M., Kuang, C., and Attoui, M.: Detection near 1-nm with a laminar-flow, water-based condensation particle counter, Aerosol Sci. Technol., 51, 354-362, https://doi.org/10.1080/02786826.2016.1262531, 2017. 
Iida, K., Stolzenburg, M. R., McMurry, P. H., and Smith, J. N.: Estimating nanoparticle growth rates from size-dependent charged fractions: Analysis of new particle formation events in Mexico City, J. Geophys. Res. Atmospheres, 113, https://doi.org/10.1029/2007JD009260, 2008.

Jen, C. N., McMurry, P. H., and Hanson, D. R.: Stabilization of sulfuric acid dimers by ammonia, methylamine, dimethylamine, and trimethylamine, J. Geophys. Res. Atmospheres, 119, 7502-7514, https://doi.org/10.1002/2014JD021592, 2014.

Jen, C. N., Hanson, D. R., and McMurry, P. H.: Toward Reconciling Measurements of Atmospherically Relevant Clusters by Chemical Ionization Mass Spectrometry and Mobility Classification/Vapor Condensation, Aerosol Sci. Technol., 49, i-iii, https://doi.org/10.1080/02786826.2014.1002602, 2015.

Jen, C. N., Bachman, R., Zhao, J., McMurry, P. H., and Hanson, D. R.: Diamine-sulfuric acid reactions are a potent source of new particle formation, Geophys. Res. Lett., 43, 867-873, https://doi.org/10.1002/2015GL066958, 2016.

Kirkby, J., Curtius, J., Almeida, J., Dunne, E., Duplissy, J., Ehrhart, S., Franchin, A., Gagne, S., Ickes, L., Kurten, A., Kupc, A., Metzger, A., Riccobono, F., Rondo, L., Schobesberger, S., Tsagkogeorgas, G., Wimmer, D., Amorim, A., Bianchi, F., Breitenlechner, M., David, A., Dommen, J., Downard, A., Ehn, M., Flagan, R. C., Haider, S., Hansel, A., Hauser, D., Jud, W., 300 Junninen, H., Kreissl, F., Kvashin, A., Laaksonen, A., Lehtipalo, K., Lima, J., Lovejoy, E. R., Makhmutov, V., Mathot, S., Mikkila, J., Minginette, P., Mogo, S., Nieminen, T., Onnela, A., Pereira, P., Petaja, T., Schnitzhofer, R., Seinfeld, J. H., Sipila, M., Stozhkov, Y., Stratmann, F., Tome, A., Vanhanen, J., Viisanen, Y., Vrtala, A., Wagner, P. E., Walther, H., Weingartner, E., Wex, H., Winkler, P. M., Carslaw, K. S., Worsnop, D. R., Baltensperger, U., and Kulmala, M.: Role of sulphuric acid, ammonia and galactic cosmic rays in atmospheric aerosol nucleation, Nature, 476, 429-433, http://www.nature.com/nature/journal/v476/n7361/abs/nature10343.html\#supplementary-information, 2011.

Kuang, C., McMurry, P. H., McCormick, A. V., and Eisele, F. L.: Dependence of nucleation rates on sulfuric acid vapor concentration in diverse atmospheric locations, J. Geophys. Res. Atmospheres, 113, https://doi.org/10.1029/2007jd009253, 2008 .

Kuang, C., Riipinen, I., Sihto, S. L., Kulmala, M., McCormick, A. V., and McMurry, P. H.: An improved criterion for new particle formation in diverse atmospheric environments, Atmos Chem Phys, 10, 8469-8480, https://doi.org/10.5194/acp-108469-2010, 2010.

Kulmala, M., Laaksonen, A., and Pirjola, L.: Parameterizations for sulfuric acid/water nucleation rates, J. Geophys. Res. Atmospheres, 103, 8301-8307, https://doi.org/10.1029/97JD03718, 1998.

Kulmala, M., Vehkamäki, H., Petäjä, T., Dal Maso, M., Lauri, A., Kerminen, V. M., Birmili, W., and McMurry, P. H.: 315 Formation and growth rates of ultrafine atmospheric particles: a review of observations, J. Aerosol Sci., 35, 143-176, http://dx.doi.org/10.1016/j.jaerosci.2003.10.003, 2004.

Kürten, A., Jokinen, T., Simon, M., Sipilä, M., Sarnela, N., Junninen, H., Adamov, A., Almeida, J., Amorim, A., Bianchi, F., Breitenlechner, M., Dommen, J., Donahue, N. M., Duplissy, J., Ehrhart, S., Flagan, R. C., Franchin, A., Hakala, J., Hansel, A., Heinritzi, M., Hutterli, M., Kangasluoma, J., Kirkby, J., Laaksonen, A., Lehtipalo, K., Leiminger, M., Makhmutov, V., Mathot, 320 S., Onnela, A., Petäjä, T., Praplan, A. P., Riccobono, F., Rissanen, M. P., Rondo, L., Schobesberger, S., Seinfeld, J. H., Steiner, G., Tomé, A., Tröstl, J., Winkler, P. M., Williamson, C., Wimmer, D., Ye, P., Baltensperger, U., Carslaw, K. S., Kulmala, M., Worsnop, D. R., and Curtius, J.: Neutral molecular cluster formation of sulfuric acid-dimethylamine observed in real time under atmospheric conditions, Proc. Natl. Acad. Sci., 111, 15019-15024, https://doi.org/10.1073/pnas.1404853111, 2014.

Kürten, A., Bianchi, F., Almeida, J., Kupiainen-Määttä, O., Dunne, E. M., Duplissy, J., Williamson, C., Barmet, P., 
M., Ickes, L., Jokinen, T., Kangasluoma, J., Kim, J., Kirkby, J., Kupc, A., Lehtipalo, K., Leiminger, M., Makhmutov, V., Onnela, A., Ortega, I. K., Petäjä, T., Praplan, A. P., Riccobono, F., Rissanen, M. P., Rondo, L., Schnitzhofer, R., Schobesberger, S., Smith, J. N., Steiner, G., Stozhkov, Y., Tomé, A., Tröstl, J., Tsagkogeorgas, G., Wagner, P. E., Wimmer, D., Ye, P., Baltensperger, U., Carslaw, K., Kulmala, M., and Curtius, J.: Experimental particle formation rates spanning tropospheric sulfuric acid and ammonia abundances, ion production rates, and temperatures, J. Geophys. Res. Atmospheres, 121, 12,377-12,400, https://doi.org/10.1002/2015JD023908, 2016.

Kürten, A., Li, C., Bianchi, F., Curtius, J., Dias, A., Donahue, N. M., Duplissy, J., Flagan, R. C., Hakala, J., Jokinen, T., Kirkby, J., Kulmala, M., Laaksonen, A., Lehtipalo, K., Makhmutov, V., Onnela, A., Rissanen, M. P., Simon, M., Sipilä, M., Stozhkov, Y., Tröstl, J., Ye, P., and McMurry, P. H.: New particle formation in the sulfuric acid-dimethylamine-water system: reevaluation of CLOUD chamber measurements and comparison to an aerosol nucleation and growth model, Atmospheric Chem. Phys., 18, 845-863, https://doi.org/10.5194/acp-18-845-2018, 2018.

Kurtén, T., Loukonen, V., Vehkamäki, H., and Kulmala, M.: Amines are likely to enhance neutral and ion-induced sulfuric acid-water nucleation in the atmosphere more effectively than ammonia, Atmospheric Chem. Phys., 8, 4095-4103, https://doi.org/10.5194/acp-8-4095-2008, 2008.

340 Larriba, C., Hogan, C. J., Attoui, M., Borrajo, R., Garcia, J. F., and de la Mora, J. F.: The Mobility-Volume Relationship below 3.0 nm Examined by Tandem Mobility-Mass Measurement, Aerosol Sci. Technol., 45, 453-467, https://doi.org/10.1080/02786826.2010.546820, 2011.

Lee, S.-H., Gordon, H., Yu, H., Lehtipalo, K., Haley, R., Li, Y., and Zhang, R.: New Particle Formation in the Atmosphere: From Molecular Clusters to Global Climate, J. Geophys. Res. Atmospheres, 124, 7098-7146, https://doi.org/10.1029/2018JD029356, 2019.

Lehtipalo, K., Yan, C., Dada, L., Bianchi, F., Xiao, M., Wagner, R., Stolzenburg, D., Ahonen, L. R., Amorim, A., Baccarini, A., Bauer, P. S., Baumgartner, B., Bergen, A., Bernhammer, A.-K., Breitenlechner, M., Brilke, S., Buchholz, A., Mazon, S. B., Chen, D., Chen, X., Dias, A., Dommen, J., Draper, D. C., Duplissy, J., Ehn, M., Finkenzeller, H., Fischer, L., Frege, C., Fuchs, C., Garmash, O., Gordon, H., Hakala, J., He, X., Heikkinen, L., Heinritzi, M., Helm, J. C., Hofbauer, V., Hoyle, C. R.,

350 Jokinen, T., Kangasluoma, J., Kerminen, V.-M., Kim, C., Kirkby, J., Kontkanen, J., Kürten, A., Lawler, M. J., Mai, H., Mathot, S., Mauldin, R. L., Molteni, U., Nichman, L., Nie, W., Nieminen, T., Ojdanic, A., Onnela, A., Passananti, M., Petäjä, T., Piel, F., Pospisilova, V., Quéléver, L. L. J., Rissanen, M. P., Rose, C., Sarnela, N., Schallhart, S., Schuchmann, S., Sengupta, K., Simon, M., Sipilä, M., Tauber, C., Tomé, A., Tröstl, J., Väisänen, O., Vogel, A. L., Volkamer, R., Wagner, A. C., Wang, M., Weitz, L., Wimmer, D., Ye, P., Ylisirniö, A., Zha, Q., Carslaw, K. S., Curtius, J., Donahue, N. M., Flagan, R. C., Hansel, A.,

355 Riipinen, I., Virtanen, A., Winkler, P. M., Baltensperger, U., Kulmala, M., and Worsnop, D. R.: Multicomponent new particle formation from sulfuric acid, ammonia, and biogenic vapors, Sci. Adv., 4, eaau5363, https://doi.org/10.1126/sciadv.aau5363, 2018.

Li, H., Ning, A., Zhong, J., Zhang, H., Liu, L., Zhang, Y., Zhang, X., Zeng, X. C., and He, H.: Influence of atmospheric conditions on sulfuric acid-dimethylamine-ammonia-based new particle formation, Chemosphere, 245, 125554, https://doi.org/10.1016/j.chemosphere.2019.125554, 2020.

McGrath, M. J., Olenius, T., Ortega, I. K., Loukonen, V., Paasonen, P., Kurtén, T., Kulmala, M., and Vehkamäki, H.: Atmospheric Cluster Dynamics Code: a flexible method for solution of the birth-death equations, Atmospheric Chem. Phys., 12, 2345-2355, https://doi.org/10.5194/acp-12-2345-2012, 2012.

McMurry, P. H. and Eisele, F. L.: Preface to topical collection on new particle formation in Atlanta, J. Geophys. Res. 
Merikanto, J., Napari, I., Vehkamäki, H., Anttila, T., and Kulmala, M.: New parameterization of sulfuric acid-ammonia-water ternary nucleation rates at tropospheric conditions, J. Geophys. Res. Atmospheres, 112, https://doi.org/10.1029/2006JD007977, 2007.

Merikanto, J., Spracklen, D. V., Mann, G. W., Pickering, S. J., and Carslaw, K. S.: Impact of nucleation on global CCN, Atmospheric Chem. Phys., 9, 8601-8616, https://doi.org/10.5194/acp-9-8601-2009, 2009.

Myllys, N., Ponkkonen, T., Passananti, M., Elm, J., Vehkamäki, H., and Olenius, T.: Guanidine: A Highly Efficient Stabilizer in Atmospheric New-Particle Formation, J. Phys. Chem. A, 122, 4717-4729, https://doi.org/10.1021/acs.jpca.8b02507, 2018.

Myllys, N., Chee, S., Olenius, T., Lawler, M., and Smith, J.: Molecular-Level Understanding of Synergistic Effects in Sulfuric Acid-Amine-Ammonia Mixed Clusters, J. Phys. Chem. A, 123, 2420-2425, https://doi.org/10.1021/acs.jpca.9b00909, 2019.

375 Olenius, T., Kupiainen-Määttä, O., Ortega, I. K., Kurtén, T., and Vehkamäki, H.: Free energy barrier in the growth of sulfuric acid-ammonia and sulfuric acid-dimethylamine clusters, J. Chem. Phys., 139, 084312, https://doi.org/10.1063/1.4819024, 2013.

Olenius, T., Halonen, R., Kurtén, T., Henschel, H., Kupiainen-Määttä, O., Ortega, I. K., Jen, C. N., Vehkamäki, H., and Riipinen, I.: New particle formation from sulfuric acid and amines: Comparison of monomethylamine, dimethylamine, and trimethylamine, J. Geophys. Res. Atmospheres, 122, 7103-7118, https://doi.org/10.1002/2017JD026501, 2017.

Ortega, I. K., Kupiainen, O., Kurtén, T., Olenius, T., Wilkman, O., McGrath, M. J., Loukonen, V., and Vehkamäki, H.: From quantum chemical formation free energies to evaporation rates, Atmospheric Chem. Phys., 12, 225-235, https://doi.org/10.5194/acp-12-225-2012, 2012.

Panta, B., Glasoe, W. A., Zollner, J. H., Carlson, K. K., and Hanson, D. R.: Computational Fluid Dynamics of a Cylindrical 385 Nucleation Flow Reactor with Detailed Cluster Thermodynamics, J. Phys. Chem. A, 116, 10122-10134, https://doi.org/10.1021/jp302444y, 2012.

Riccobono, F., Rondo, L., Sipilä, M., Barmet, P., Curtius, J., Dommen, J., Ehn, M., Ehrhart, S., Kulmala, M., Kürten, A., Mikkilä, J., Paasonen, P., Petäjä, T., Weingartner, E., and Baltensperger, U.: Contribution of sulfuric acid and oxidized organic compounds to particle formation and growth, Atmospheric Chem. Phys., 12, 9427-9439, https://doi.org/10.5194/acp-12-9427$390 \quad 2012,2012$.

Riccobono, F., Schobesberger, S., Scott, C. E., Dommen, J., Ortega, I. K., Rondo, L., Almeida, J., Amorim, A., Bianchi, F., Breitenlechner, M., David, A., Downard, A., Dunne, E. M., Duplissy, J., Ehrhart, S., Flagan, R. C., Franchin, A., Hansel, A., Junninen, H., Kajos, M., Keskinen, H., Kupc, A., Kürten, A., Kvashin, A. N., Laaksonen, A., Lehtipalo, K., Makhmutov, V., Mathot, S., Nieminen, T., Onnela, A., Petäjä, T., Praplan, A. P., Santos, F. D., Schallhart, S., Seinfeld, J. H., Sipilä, M., 395 Spracklen, D. V., Stozhkov, Y., Stratmann, F., Tomé, A., Tsagkogeorgas, G., Vaattovaara, P., Viisanen, Y., Vrtala, A., Wagner, P. E., Weingartner, E., Wex, H., Wimmer, D., Carslaw, K. S., Curtius, J., Donahue, N. M., Kirkby, J., Kulmala, M., Worsnop, D. R., and Baltensperger, U.: Oxidation Products of Biogenic Emissions Contribute to Nucleation of Atmospheric Particles, Science, 344, 717-721, https://doi.org/10.1126/science.1243527, 2014.

Sihto, S. L., Kulmala, M., Kerminen, V. M., Dal Maso, M., Petäjä, T., Riipinen, I., Korhonen, H., Arnold, F., Janson, R., Boy, 400 M., Laaksonen, A., and Lehtinen, K. E. J.: Atmospheric sulphuric acid and aerosol formation: implications from atmospheric measurements for nucleation and early growth mechanisms, Atmos Chem Phys, 6, 4079-4091, https://doi.org/10.5194/acp-64079-2006, 2006.

Simon, M., Heinritzi, M., Herzog, S., Leiminger, M., Bianchi, F., Praplan, A., Dommen, J., Curtius, J., and Kürten, A.: Detection of dimethylamine in the low pptv range using nitrate chemical ionization atmospheric pressure interface time-of- 
flight (CI-APi-TOF) mass spectrometry, Atmospheric Meas. Tech., 9, 2135-2145, https://doi.org/10.5194/amt-9-2135-2016, 2016.

Sipilä, M., Berndt, T., Petäjä, T., Brus, D., Vanhanen, J., Stratmann, F., Patokoski, J., Mauldin, R. L., Hyvärinen, A.-P., Lihavainen, H., and Kulmala, M.: The Role of Sulfuric Acid in Atmospheric Nucleation, Science, 327, 1243-1246, https://doi.org/10.1126/science.1180315, 2010.

410 Sipilä, M., Sarnela, N., Jokinen, T., Junninen, H., Hakala, J., Rissanen, M. P., Praplan, A., Simon, M., Kürten, A., Bianchi, F., Dommen, J., Curtius, J., Petäjä, T., and Worsnop, D. R.: Bisulfate \&ndash; cluster based atmospheric pressure chemical ionization mass spectrometer for high-sensitivity (\&lt; $100 \mathrm{ppqV})$ detection of atmospheric dimethyl amine: proof-of-concept and first ambient data from boreal forest, Atmospheric Meas. Tech., 8, 4001-4011, https://doi.org/10.5194/amt-8-4001-2015, 2015 .

415 Spracklen, D. V., Carslaw, K. S., Kulmala, M., Kerminen, V.-M., Mann, G. W., and Sihto, S.-L.: The contribution of boundary layer nucleation events to total particle concentrations on regional and global scales, Atmospheric Chem. Phys., 6, 5631-5648, https://doi.org/10.5194/acp-6-5631-2006, 2006.

Spracklen, D. V., Carslaw, K. S., Kulmala, M., Kerminen, V.-M., Sihto, S.-L., Riipinen, I., Merikanto, J., Mann, G. W., Chipperfield, M. P., Wiedensohler, A., Birmili, W., and Lihavainen, H.: Contribution of particle formation to global cloud condensation nuclei concentrations, Geophys. Res. Lett., 35, https://doi.org/10.1029/2007GL033038, 2008.

Wang, C.-Y., Jiang, S., Liu, Y.-R., Wen, H., Wang, Z.-Q., Han, Y.-J., Huang, T., and Huang, W.: Synergistic Effect of Ammonia and Methylamine on Nucleation in the Earth's Atmosphere. A Theoretical Study, J. Phys. Chem. A, 122, 34703479, https://doi.org/10.1021/acs.jpca.8b00681, 2018.

Weber, R. J., Marti, J. J., McMurry, P. H., Eisele, F. L., Tanner, D. J., and Jefferson, A.: Measured atmospheric new particle formation rates: implications for nucleation mechanisms, Chem. Eng. Commun., 151, 53-64, https://doi.org/10.1080/00986449608936541, 1996.

Weber, R. J., Marti, J. J., McMurry, P. H., Eisele, F. L., Tanner, D. J., and Jefferson, A.: Measurements of new particle formation and ultrafine particle growth rates at a clean continental site, J. Geophys. Res. Atmospheres, 102, 4375-4385, https://doi.org/10.1029/96JD03656, 1997.

430 Weber, R. J., McMurry, P. H., Mauldin, L., Tanner, D. J., Eisele, F. L., Brechtel, F. J., Kreidenweis, S. M., Kok, G. L., Schillawski, R. D., and Baumgardner, D.: A study of new particle formation and growth involving biogenic and trace gas species measured during ACE 1, J. Geophys. Res. Atmospheres, 103, 16385-16396, https://doi.org/10.1029/97JD02465, 1998.

Xie, H.-B., Elm, J., Halonen, R., Myllys, N., Kurtén, T., Kulmala, M., and Vehkamäki, H.: Atmospheric Fate of Monoethanolamine: Enhancing New Particle Formation of Sulfuric Acid as an Important Removal Process, Environ. Sci.

Technol., 51, 8422-8431, https://doi.org/10.1021/acs.est.7b02294, 2017.

Yao, L., Garmash, O., Bianchi, F., Zheng, J., Yan, C., Kontkanen, J., Junninen, H., Mazon, S. B., Ehn, M., Paasonen, P., Sipilä, M., Wang, M., Wang, X., Xiao, S., Chen, H., Lu, Y., Zhang, B., Wang, D., Fu, Q., Geng, F., Li, L., Wang, H., Qiao, L., Yang, X., Chen, J., Kerminen, V.-M., Petäjä, T., Worsnop, D. R., Kulmala, M., and Wang, L.: Atmospheric new particle formation from sulfuric acid and amines in a Chinese megacity, Science, 361, 278-281, https://doi.org/10.1126/science.aao4839, 2018.

440 Yu, F. and Luo, G.: Simulation of particle size distribution with a global aerosol model: contribution of nucleation to aerosol and CCN number concentrations, Atmospheric Chem. Phys., 9, 7691-7710, https://doi.org/10.5194/acp-9-7691-2009, 2009. 
Yu, F., Nadykto, A. B., Herb, J., Luo, G., Nazarenko, K. M., and Uvarova, L. A.: $\mathrm{H}_{2} \mathrm{SO}_{4}-\mathrm{H}_{2} \mathrm{O}-\mathrm{NH}_{3}$ ternary ion-mediated nucleation (TIMN): kinetic-based model and comparison with CLOUD measurements, Atmospheric Chem. Phys., 18, 1745117474, https://doi.org/10.5194/acp-18-17451-2018, 2018.

$445 \mathrm{Yu}, \mathrm{H} .$, McGraw, R., and Lee, S.-H.: Effects of amines on formation of sub-3 nm particles and their subsequent growth, Geophys. Res. Lett., 39, L02807, https://doi.org/10.1029/2011GL050099, 2012.

Zhang, R., Suh, I., Zhao, J., Zhang, D., Fortner, E. C., Tie, X., Molina, L. T., and Molina, M. J.: Atmospheric New Particle Formation Enhanced by Organic Acids, Science, 304, 1487-1490, https://doi.org/10.1126/science.1095139, 2004.

Zhao, B., Shrivastava, M., Donahue, N. M., Gordon, H., Schervish, M., Shilling, J. E., Zaveri, R. A., Wang, J., Andreae, M. 450 O., Zhao, C., Gaudet, B., Liu, Y., Fan, J., and Fast, J. D.: High concentration of ultrafine particles in the Amazon free troposphere produced by organic new particle formation, Proc. Natl. Acad. Sci., 117, 25344-25351, https://doi.org/10.1073/pnas.2006716117, 2020.

Zhao, J., Khalizov, A., Zhang, R., and McGraw, R.: Hydrogen-Bonding Interaction in Molecular Complexes and Clusters of Aerosol Nucleation Precursors, J. Phys. Chem. A, 113, 680-689, https://doi.org/10.1021/jp806693r, 2009.

455 Zhao, J., Eisele, F. L., Titcombe, M., Kuang, C., and McMurry, P. H.: Chemical ionization mass spectrometric measurements of atmospheric neutral clusters using the cluster-CIMS, J. Geophys. Res. Atmospheres, 115, https://doi.org/10.1029/2009JD012606, 2010.

Zhao, J., Ortega, J., Chen, M., McMurry, P. H., and Smith, J. N.: Dependence of particle nucleation and growth on highmolecular-weight gas-phase products during ozonolysis of $\alpha$-pinene, Atmospheric Chem. Phys., 13, 7631-7644, https://doi.org/10.5194/acp-13-7631-2013, 2013.

Zollner, J. H., Glasoe, W. A., Panta, B., Carlson, K. K., McMurry, P. H., and Hanson, D. R.: Sulfuric acid nucleation: power dependencies, variation with relative humidity, and effect of bases, Atmos Chem Phys, 12, 4399-4411, https://doi.org/10.5194/acp-12-4399-2012, 2012. 